\title{
Post-cold War Ethiopian Land Policy and State Power in Land Commercialisation
}

\author{
Teshome Emana Soboka
}

\begin{abstract}
Land policy is one of the issues that affects the lives of millions of people in Ethiopia. The main purpose of this chapter is to explore how the policy has become instrumental for state land commercialisation after the 1991 regime change when the guerrilla fighter group - the Ethiopian People's Revolutionary Democratic Front (EPRDF) — took power by overthrowing the military dictatorial government. Based on the data gathered from various sources, the chapter argues that the government has implemented different land policies, all of which were used to strengthen state power over land ownership. This state land monopolisation assisted the government to commercialise land by developing state-sponsored institutions that have been catalysing the process of land transaction in favour of large-scale commercial farming. At the beginning of its coming to power, the EPRDF-led government promised to overhaul the land policy of the country with the objective to ensure fair access to land for the citizens. In the meantime, however, all the legal frameworks were directed towards the strengthening of state power over land. This state domination over land ownership brought about several unintended outcomes, such as corruption and unfair access to the land, which, in turn, resulted in mistrust between the state and society.
\end{abstract}

Keywords Ethiopia · Corruption · Institutions · Land commercialisation · Land policy

T. E. Soboka $(\otimes)$

Addis Ababa University, Addis Ababa, Ethiopia

(C) The Author(s) 2022

S. Takeuchi (ed.), African Land Reform Under Economic Liberalisation, https://doi.org/10.1007/978-981-16-4725-3_8 


\section{Introduction}

The year 1991 marked the end of the global Cold War; the year also had enormous significance as regards the political economy of Ethiopia, for it marked a regime change in the country. In May 1991, the Ethiopian Peoples' Revolutionary Democratic Front (EPRDF), which was once a guerrilla fighter group, overthrew the dictatorial military government (Derg), which had lasted in power for 17 years (1974-1991). The new regime was established as a transitional government until the country enacted a new constitution in 1995. Since then, land and land policy have been central to the socio-economic and political debates within the country. Land plays an important role in realising the efficiency of all the robust envisaged increases in agricultural productivity and improving citizens' livelihoods (USAID 2004, 3) as the landholding issue is 'not simply an economic affair' (Nega et al. 2003, 103) but 'intrinsically connected to political, social, and cultural identity' of the people.

Several studies have exposed the land tenure systems of Ethiopia from different perspectives. Some of these studies were historical, others political, and some others based their studies on economic grounds. Pankhurst (1966) attempted to provide a historical picture of Ethiopian land tenure from the time of the kingdom of Axumup to the twentieth century. Rahmeto $(1984,1992,1994,2011)$ has documented the historical, political, and economic significance of land and land policies in Ethiopia. He argued that interventionism and statism were the central elements of land-related policy management in the country, where the former imposed uniformity in the success of developmental activities while the second, statism, asserted that the 'state is the chief actor, thinker, planner, and the main provider of all benefits' (Rahmeto 1994, 1). This has left the Ethiopian land policy issue as 'unfinished business' (Rahmeto 1994, 13). Therefore, he suggested an alternative approach-associative ownership to argue that land should be owned by the community and individual land users (Rahmeto 1994, 14). Hebo $(2006,20)$ categorised the Ethiopian land tenure systems of the imperial period as 'the North' and 'the South, where the North referred to Abyssinia proper (the Amhara and the Tigrean) and the South referred to all the conquered and subjugated people in almost every part of the empire regardless of their geographical location. This is in line with Hoben (1973), Rahmeto (1984, 1994), Crummey (2000), and Zewde (2001), who dichotomised the Ethiopian land tenure systems into North and South prior to the 1975 land reform. The North had what we call the rist system, with its various forms, while the South was manifested by private and government land ownership (Solomon 2020, 34). Other studies by Nega et al. (2003), Rahmeto (2011), and Solomon (2020) examined Ethiopian land policy mainly from the economic and political aspects within the framework of state-society relationship, since government always assumes a central role in land ownership. So, in Ethiopia where land is still a political tool, it is imperative to study land policy owing to two main reasons.

First, the country has no colonial legacy since it has never been colonised, except the five-year Italian occupation (1936-1941), which did not, unlike with the other European colonisers in Africa, in any real sense have a significant influence on 
Ethiopian land policy. Larebo (1994) reviewed the land and agricultural policy schemes that the Italian colonial government brought to Ethiopia in terms of three interrelated schemes. The first one was the resettlement of military veteran soldiers in strategic geographical areas of Ethiopia so that a peasantry could be created to protect the colonial system. The second scheme was what Larebo calls 'demographic colonization' to refer to the facilitation of the relocation of Italians from highly populated areas to defined Ethiopian localities. This, of course, was to support the third scheme in the colonial plan - the realisation of Italian commercial farming in Ethiopia. All three schemes did not work in part due to strong resistance from the already established indigenous land tenure system in Ethiopia and partly due to the fact that the settlers from Italy could not withstand the harsh climate conditions in Ethiopia. Above all, although Italians developed the above schemes to transform Ethiopia's agriculture into a colonial format, strong opposition from the Ethiopian side forced the Italians to retreat before they could implant their legacy in Ethiopia's land policy.

Therefore, apart from the expansion of infrastructure, such as the Ethio-Djibouti railway and various roads, which were built to access mineral resource abundant areas, there is no observable legacy of Italian colonial land policy in Ethiopia. Of course, the construction of roads and the implementation of new urban designs contributed to the emergence of new urban settlements along the new roads, and fascist architecture and urbanism in Ethiopia (González-Ruibal 2010, 6). ${ }^{1}$ The Italian fascist architecture and urbanism bequest is somewhat visible in deconstructing indigenous cities to make them appear as colonial cities where the roads and houses were designed in European styles and even reflect racial segregation in the naming of neighbourhoods in cities such as Addis Ababa. While undertaking these construction activities for their own sake, Italians did not dare or get time to make profound land policy reforms. That is why, Crewett et al. $(2008,6)$ argue, in Ethiopia one cannot find the colonial heritage experienced in other sub-Saharan African countries, brought about through land grabbing by European settlers, which contributed to the institutionalisation of private property rights to land. Yet, Binayew (2015) argues that 'the traditional land tenure system was disrupted' because the Italian rulers took the gult and rist lands of Ethiopians in the North and distributed them to their loyal servants. This exhibited the Italian colonial land-grabbing policy during their brief occupation, which weakened the land-owning nobilities in those parts of the country. Mengistie, cited in Binayew (2015), also considers this a turning point in the history of the lord-tenancy relationship in Ethiopia. But, Crewett et al. $(2008,6)$ argue that 'the colonial legacy in Ethiopia is rather an imperial colonialism in the second half of the nineteenth century with the expansion of the Abyssinian Empire towards the South and the imposition of an exploitative land tenure system in the conquered territories'. These parts, as different from the North, include 'the concurred and subjugated

\footnotetext{
${ }^{1}$ Bertazzini $(2018,5)$ argues that massive road construction projects connecting the main cities with asphalt roads were undertaken during those five years. From 1935 to 1936, for example, 'the main sections of the Asmara-Gondar, Asmara-Dessié-Addis Ababa, Addis Ababa-Jimma, Addis Ababa-Lechemti (Nekemete) and Addis Ababa-Harar-Mogadishu roads were completed. In the following years (1937-1939) some other paved roads were built, namely the Addis Ababa-Debra Tabor and Assab-Dessié roads'.
} 
people in almost every part of the empire regardless of their actual geographical location' (Hebo 2006, 20). Since then, land policy and land tenure issues have been real sources of contention and a means of power consolidation in Ethiopia.

Second, since the imperial period Ethiopia has never exercised a land policy that frees land tenure rights from the strong grip of the state in modern Ethiopia, because land policy is the 'real source of power in imperial and in present day Ethiopia, being the centre of policy debates' (Crewett et al. 2008, 1). Furthermore, Lavers (2018) argues that Ethiopia seems to be special as it has a somewhat consistent system of state land ownership despite regime changes. Of course, each regime state used to appear with its own particular plan to use land for its own power accumulation. Thus, this chapter explores how state power got a strong land commercialising effect after the Cold War, the post-Derg period in Ethiopia.

During the Cold War, Ethiopia was stretched between the two world blocks (the capitalist American camp and the socialist Soviet camp), which influenced the land policies of the country in one way or the other. The one influenced by the capitalist block was imperial Haile Selassie's landholding policy, which lasted for 40 years (1933-1974), in which both customary and statutory land tenures were in practice with various forms such as lineage (rist and gult), private, and state ownerships. During the Cold War, particularly from the mid-1970s, there was a movement called the Ethiopian Student Movement of the socialist progressive group, to ensure an egalitarian land holding system that would break the landlord-tenant relationship. Yet, there still existed debates on whether the country should privatise land or keep it under state ownership. These debates are still going on, although the present government advocates state ownership of land by leaving only usufruct rights for the holders (Constitution 1995; Crewett et al. 2008; González-Ruibal 2010).

The government justifies its position based on two main rationales. The first, not different from that of the Derg regime (1974-1991), asserts that, historically, Ethiopian farmers experienced land deprivation and forceful dispossession during the imperial period and that this should be stopped once and for all. ${ }^{2}$ Second, the government advocates that state ownership of land ensures justice in land access for every citizen. The government has taken an unshakable stand in this regard and labels arguments against it to be politically motivated (Rahmeto 1994, 2004; Adal 2002; Crewett and Korf 2008). There are generous promises in government documents, such as the Constitution, at least on paper, that all citizens have the right to access land and the protection of property rights. For example, the 1995 Constitution guarantees that Ethiopian peasants have the right to protection against eviction from their possession (article 40(4)) and the same for pastoralists - they are protected against displacement from their land (article 40(5)). Yet the realities and the results of various studies (Rahmeto 2011; Gebresenbet 2016) show that peasants and pastoralists are being dispossessed of their lands due to public or private development

\footnotetext{
2 The Tigrean Peoples' Liberation Front, due to the socialist/communist background of its leaders, continued to promote egalitarian type of land tenure, which was no different from the Derg because, in its declaration on economic policy in November 1991 (Transitional Government of Ethiopia 1991), it announced the continuation of the land policy. But later, the country's free-market economic policy upset this stand and put land under complicated commercial purposes.
} 
projects by domestic and foreign investors. Acquiring large tracts of land and leasing them to investors has resulted in the dispossession of several peasant and pastoralist communities in Ethiopia, which, in turn, has rendered impotent of the government's promise to ensure citizens' access to land.

Thus, this chapter examines post-Cold War Ethiopian land policy and state power in land commercialisation. First, it presents an overview of Ethiopian land policy before 1991, to connect the past and the present. Then, post-Cold War land policy will be discussed with the main emphasis on government strategies of land commercialisation. Then, the roles of overseas development agencies will be discussed. The final part includes concluding remarks. The chapter is based on data from extensive analysis of existing government land policy documents, empirical data from previous studies, and the author's own observations and interviews.

\section{An Overview of Ethiopian Land Policy from the Imperial to the Derg Period}

Ethiopian land policy before the end of the Cold War was much complicated but, for brevity, it can be divided into two: the imperial period and the Derg period. Adal $(2002,2)$ argues that land tenure during the imperial period was so complex that it is difficult to have a complete picture of it: 'Ethiopia has one of the most intricate land tenure systems in the world' (Cohen 1973, 366). This complexity has made it difficult to improve the land reform system of the country, and thereby, affected land productivity. In both the Menelik and Haile Selassie regimes, the 'pre-1974 Ethiopian land regime was typically a feudal system where land was concentrated in the hands of landlords and the Orthodox Christian Church. Land tenure rights were highly insecure because it was highly characterised by arbitrary evictions of citizens' (Cotula 2007, 5).

Broadly speaking, land tenure during the imperial period can be either of the North or South type. In the northern areas, such as Gojjam and Tigray, there were different tenure systems, such as 'communal (rist), grant land (gult), freehold, or sometimes referred to as private (gebbar tenures), church (samon), and state (maderia, mengist) tenure regimes' (Crewett and Korf 2008, 7).

According to Cohen and Weintraub (1975) and Adal (2002), rist is the right to claim a share of land based on kinship from a historical ancestor held in common with other rist holders. 'Those who can establish kinship through either parent may enter a claim to a share of the land in a unit from elders controlling the allocation of land held by what is in effect a descent corporation' (Adal 2002, 4), but it does 'not guarantee equal access to land to all dwellers of the area. Individuals' access to land was highly determined by their social status' (Hoben 1973; Rahmeto 1984, 1994). Conversely, Hoben explains that gult rights over land were given to members of the ruling elite as a reward for loyal service to their lord and to religious institutions as 
endowments; they were granted the right to collect taxes from those who tilled it. The rist and gult systems were complementary types of land rights.

The imperial period was also characterised by a private land tenure system that was prevalent in the southern and south-western part of Ethiopia. This landholding pattern is the most dominant tenure, affecting over $60 \%$ of Ethiopia's peasants (Mengisteab 1990) and prevailing in the areas where $65 \%$ of the Ethiopian population lived (Cohen and Weintraub 1975). According to Cohen and Weintraub $(1975,35)$, private tenures were created when the crown confiscated the land ${ }^{3}$ conquered by its armies and granted vast blocks to a wide range of people and institutions. Rahmeto (1984) stated that these confiscated lands were granted to soldiers, northern civil servants who came from Gojjam, Gondar, Wollow, and Tigray to administer the new conquered areas, and to those peasants who migrated southward due to land hunger in the north. In addition, local traditional village leaders who did not resist the crown conquest, and church officials and institutions who facilitated the expansion of the Coptic religion towards new areas in the south and west, had similar privileges.

In addition to rist and gult, church land was another form of tenure in the imperial regime in which the Ethiopian Orthodox Church was an important landholding entity. However, the size of land held by the church was not well documented because of the 'complexity of the forms, the decentralized nature of ownership of church lands and due to the secrecy of the church's central treasury' (Cohen and Weintraub 1975, see also Rahmeto 1984; Mengisteab 1990, 51). Much of the church lands were in the south, estimated to be 25-50\% (Cohen and Weintraub 1975) of the total land area of the country. Yet, Rahmeto (1984) reduced the estimate, saying it would not exceed $10-12 \%$, which was obtained through grants from the crown designated as semon land and gult land. Semon land was given to functionaries in place of salary, while gult lands was given to the administrators of churches and the high priests (Adal 2002 , 1). Finally, state land included all the unoccupied lands whose tenure system was 'freehold', which refers to the land distributed to men of influence and power in the state apparatus, and which was later converted into private tenures. Land under private ownership could be sold or exchanged without any restrictions except those provided by law. ${ }^{4}$

The other pre-Cold War land policy worth considering was the 'Derg Land Policy'. The political change in 1974 led to a sweeping land reform, with its Proclamation No. 31/1975 (Public Ownership of Rural Lands Proclamation), the aim of which

\footnotetext{
3 Teshome $(2016,113)$ argues that the land tenure system during this period was characterised by absolute power imbalance between feudal lords and peasants, given the importance of land resource as a source of power that served the monarchy and the feudal land lords as an institution to exploit the masses. The emperor had absolute rights over all land with the authority to grant and withdraw land rights at all levels. The power of the emperor was clearly asserted in the 1931 Constitution and the 1955 revised Ethiopian Constitution. He further elaborated that the southern part of the country was affected by massive political intervention, in the form of and grabbing favouring landlords and political authorities.

${ }^{4}$ Rahmeto (1984) argues that lands under private tenures were private not in the strict capitalist sense, because what the state had granted was originally state property. Such lands, which were given to settlers and commercial farmers who came from outside the areas, were common in the nomadic areas.
} 
was to confiscate rural land from those who held it and provide equal access for all farmers (Teklu and Adugna 2004), and Proclamation No. 47/1975 (A Proclamation to Provide for Government Ownership of Urban Lands and Extra Urban Houses). In addition to claiming that a person's rights, honour, status, and standard of living are determined by his relation to land, Proclamation No. 31/1975 was intended to end the serfdom condition under which a majority of the Ethiopian population was living: it made 'rural land the collective property of the Ethiopian people' (Schwab 1978, 50). Thus, redistributive land reform transferred usufruct rights to the rural peasantry, maintaining the continuity of state land ownership. The policy put all rural land under state ownership without compensation to pervious right holders and prohibited tenancy relations [article 4(5)].

Peasant associations (PA) were given administrative and judicial powers, and the mandate to allocate land (Tesfaye 2003, 6). In addition, agrarian collectivisation, such as farmers producers' cooperatives and the Rural Villagisation Programme, were established in the 1980s because smallholder farmers were believed to be inefficient to take advantage of economies of scale. Furthermore, large-scale state farms ${ }^{5}$ spreading over 75,000 ha of land were established by procuring land from individually owned commercial farms; this was later expanded to about 216,000 ha in 1987/1988 (Ofcansky and Berry 1991). These farms were mainly located in southern and western parts of the country, such as Sidamo, Wollega, and Illu Abbabor. The tenyear plan of the Derg regime indicated that state farms would expand to 468,000 ha by 1994, accounting for 6.4\% of the cultivated land (Ofcansky and Berry 1991). Unfortunately, this plan did not materialise as the EPRDF came to power in 1991, whose interest, as opposed to the socialist Derg regime, was to move towards 'free-market' economic policy. Following the rural land law, a radical urban land law came into being. In Proclamation No. 47/1975, the Derg military government posited that it would be necessary to 'bridge the wide gap in the standard of living of urban dwellers by appropriate allocation of disproportionately held wealth and income as well as the inequitable possession of services among urban dwellers and to eliminate the exploitation of the many by the few'.

Despite the radical change in land ownership from the 'Land to the tillers' motto to the 'Urban Land and Urban Extra Houses' laws, there has been severe criticisms of the land policy of the Derg regime, mainly from those who argue in favour of land privatisation, because land rights were highly controlled; transfer through sales, lease, or mortgage was entirely prohibited, and inheritance was highly regulated (Crewett et al. 2008). Lavers $(2018,2)$ strengthens the above criticism.

While the significance of the 1975 land reform is indisputable, nonetheless there remains ambiguity in land tenure regarding the authority of state and non-state actors

\footnotetext{
${ }^{5}$ In sub-article 7.1 of Proclamation No. 31/1975, it is declared that any large-scale farm shall be organised as a state or a cooperative farm or shall be allotted to tillers; provided that until the establishment of state or cooperative farms the government shall administer such farms in any manner it deems fit and provided further that until the government decides upon the manner in which such farms are to be administered, the ex-owners of these farms shall have the responsibility to continue administering them.
} 
and the implications of different land tenure institutions for citizenship. This ambiguity is partly due to the continuing influence of neo-customary tenure regimes, which in many places were not actually wiped out by state ownership, and, arguably, have become increasingly influential in recent years.

In general, there is a continuous debate whether the Derg land policy ensured land tenure security - according to me, it did both. However, since the scope of this chapter is to analyse Ethiopian land policy after 1991 (after the Cold War), I will not engage in providing evidence whether the Derg land policy really had both constructive and destructive effects on the lives of the Ethiopian majority.

\section{Land Policy After the Cold War}

The EPRDF-led government that took power in 1991 following the downfall of the Derg regime promotes a 'free market' economic policy under its 'Democratic Developmental State' ideology, which has made no substantive change to the state ownership of land. The 1995 Ethiopian Constitution draws a broad framework for land policy in the country and enshrines the concept of public land ownership and the inalienability of landholdings. It asserts that there are no private property rights in land. In the Constitution, some important articles, such as articles 40 and 89, provide for state power over land. Article 40(3) states:

the right to ownership of rural and urban land, as well as of all natural resources, is exclusively
vested in the state and the peoples of Ethiopia. Land is a common property of the nations,
nationalities and peoples of Ethiopia and shall not be subject to sale or to other means of
exchange.

In addition, article $89(5)$ of the Constitution provides that the state, on behalf of the people, will manage land. ${ }^{6}$

Regional states are given the power to administer land within their administration consistent with the provisions in the Constitution and other federal laws such as Proclamation No. 89/97, the Federal Rural Land Administration and Use Proclamation, which gives the regional states the power to make laws to manage and administer land within their boundaries. This power, among others, includes determining systems for land expropriation and compensation, land lease, communal rights, and land use planning. Accordingly, each region has its own unique laws, rules, and practices and incentives for agriculture land lease fees, whereas Proclamation No. 29/2001 (EC) provides that plots over 5000 ha be administered by federal authorities and included in the land bank. The following sections of this chapter, therefore, discuss federal land laws that have direct bearing on the government power of land commercialisation after the 1991 regime change, which we refer to as the post-Cold War period.

${ }^{6}$ Article 89(5) of the Constitution states that 'Government has the duty to hold, on behalf of the People, land and other natural resources and to deploy them for their common benefit and development'. 
After farmers associations were quickly dissolved in 1991, it was confirmed by the transitional government (1991-1995) that there would be no change in the state ownership of land, which later was enshrined in the 1995 Constitution [article 40(3)]. It 'established a non-flexible land policy in the country' (Temesgen 2020, 7) as it stipulates that the federal government shall enact laws for the utilisation and conversation of the land and other natural resources [article 51(5_)]. With this constitutional background, the first federal rural land administration law (Proclamation No. 89/1997) was enacted though, later, it was repealed by the Rural Land Administration and Use Proclamation No. 456/2005. This is the governing law that regulates rural land administration in the country today. Consistent with the Constitution, the law, in its preamble, states that the main purpose is ensuring tenure security, strengthening property rights of farmers, sustainably conserving and developing natural resources, and establishing a land database and conducive land administration in the country. This statement is both a promise and indicative in its nature. It is promising, though arguable when implemented, in that the rural land tenure security would be ensured. It is also indicative of the upcoming land registration and certification processes in the country.

Together with the above proclamation, Proclamation No. 455/2005, Expropriation of Landholdings for Public Purposes and Payment of Compensation, ${ }^{7}$ was enacted to enable the government to dispossess land and transfer it to others in the name of 'public purpose'. What difference will this proclamation make? Firstly, there is an issue of compensation upon expropriation of land holdings. Article (1) of this proclamation mandates woreda (districts) or urban administrations to make an advance payment of compensation for expropriation based on the decision made by the appropriate higher regional or federal government organ for the same purpose. There are two concepts that need clarification here: 'appropriate higher body' and 'public purpose'. Who decides that a certain organ is the appropriate body to expropriate land and pay compensation, or who proves that the land is actually taken for public purposes? These are self-explanatory questions since the ownership of land is constitutionally vested in the state, and the 1997 Rural Land Administration Proclamation delegates regional governments to assign holding rights and to allocate landholdings. In addition, the federal 'Poverty Reduction Strategy' (PASDEP

\footnotetext{
${ }^{7}$ Another proclamation, Proclamation No. 1161/2019, was made to ensure the continuation of land expropriation but appeared with a new settlement package, named Expropriation of Landholdings, Payment of Compensation, and Resettlement.
} 
I) ${ }^{8}$ states that every farmer who wants to make a livelihood from farming is entitled to a piece of land free of charge.

But the overall rural land tenure policy of the country faces many challenges because 'there is often a wide gap between rights on paper and rights in practice, where land policy is understood as political power policy in agrarian societies such as Ethiopia' (Crewett et al. 2008, 5). This is due to variations in interpretation of the law by officials at various levels. Moreover, there is a contradiction between what is written and what is practised because, although land administration is decentralised to the regional governments, the federal government still assumes much power in formulating fundamental land policy. So, the federal government seems to assume an all-time interference in the regional governments' power over land administration and can directly allocate land in the regions for any purpose of public or private development projects without the knowledge of the concerned regional governments. Notification letters suffice in this regard. Furthermore, Temesgen $(2020,69)$ argues that regional legislation is not comprehensive in that they focus on farmers and few provisions concern pastoralists and agro-pastoralists even though a significant proportion of the Ethiopian rural population is pastoralists and agro-pastoralists. Thus, he further argues that rural land administration law lacks a focus on the land rights of pastoralists and semi-pastoralists, although pastoral communities are estimated to be $12-15$ million (14-18\% of the total population) who occupy $60-65 \%$ of the country's land area (UNICEF 2019:1).

\section{Post-Cold War Land Commercialisation Schemes}

The present Ethiopian federal government has some institutions in place that help it to concentrate the power of land ownership in both rural and urban areas. Largescale agricultural investment, land bank, using loan-giving institutions (mainly stateowned), and rural land registration are a few of the land monopolising schemes as discussed below.

\footnotetext{
8 PASDEP stands for 'A Plan for Accelerated and Sustained Development to End Poverty' (PASDEP) (2005/06-2009/10). The objectives of the PASDEP are to define the nation's overall strategy for development for the coming five years; to lay out the directions Ethiopia wants to take, with the ultimate objective of eradicating poverty; and to outline the major programmes and policies in each of the major sectors. Although the PRSP process started in 2000 as a process largely between government and donors in Ethiopia, it has now evolved beyond that, and the PASDEP is now considered a national plan for guiding all developmental activities during the coming five years. Additionally, it is a nationally agreed development plan belonging to all Ethiopians, developed through a process of consultation among all elements of society (Ministry of Finance and Economic Development 2006: 1). This is followed by GTP I and GTP II.
} 
Table 1 Total land transferred from regions to Federal Land Bank for investment

\begin{tabular}{l|l|l|l|l}
\hline S.No. & Region & Land in Federal Land & \multicolumn{2}{l}{ Land transferred to investors } \\
\cline { 4 - 6 } & & & No. of investors & Size (ha) \\
\hline 1 & Gambella & $1,226,893$ & 45 & 220,812 \\
\hline 2 & Benishangul Gumuz & $1,149,047$ & 72 & 115,054 \\
\hline 3 & SNNPRS & 209,723 & 20 & 69,718 \\
\hline 4 & Oromia & $1,079,974$ & - & - \\
\hline 5 & Amhara & 6,183 & - & - \\
\hline 6 & Somali & 6,000 & - & - \\
\hline Total & & $3,677,820$ & 137 & 405,584 \\
\hline
\end{tabular}

Source Ministry of Agriculture (2020)

\subsection{Large-Scale Agricultural Investment}

The EPRDF (now Prosperity Party) government made a total shift from state-owned large-scale farms to private large-scale agricultural investment with the assumption that this would improve land productivity, access to technology, job opportunities, diversification of the local economy, increase income, market linkages, and attract complementary investment (Ministry of Agriculture 2020). In the last ten years, the government of Ethiopia has divided its development policy in all sectors into two: GTP I (2011-2015) and GTP II (2016-2020). Ethiopia's Growth and Transformation Plan I (2010/11-2014/15) aimed at achieving the country's longterm vision and sustaining rapid and broad-based economic growth, while GTP II (2016-2020) $)^{9}$ aims to spur economic structural transformation and sustain accelerated growth towards the realisation of the national vision to become a low middleincome country by 2025 . During these policy implementation years, due to the shift of pro-capital land policies, large-scale agriculture investment gained momentum by transferring large areas of land to the Federal Land Bank, and thereby leasing to both domestic and private investors. According to Rahmeto $(2011,11)$ the land to be transferred to large-scale investors in the first GTP was expected to increase from 0.5 million ha in 2011 to 2.8 million ha in 2013, and 3.3 million ha in 2015 .

Table 1 shows the size of land transferred to the Federal Land Bank, land transferred to investors for large-scale agriculture investment, and the number of investors during the second Growth and Transformation Plan ${ }^{10}$ (GTP II) period.

\footnotetext{
${ }^{9}$ This Growth and Transformation Plan is an exhaustive and ambitious document that assumes the partnership of several countries and donor agencies for its success (See the plan document for the objectives for each sector.).

${ }^{10}$ Since the beginning of the new reform in April 2018, the Ethiopian government has no intention to declare whether it is still implementing the second Growth and Transformation Plan. Yet, one cannot see any new economic development policy produced by the new reformist government under Prime Minister Abiy Ahmed.
} 
Table 2 Large-scale agricultural investment products in GTP II (2016-2020)

\begin{tabular}{l|l|l}
\hline \multirow{2}{*}{ Years } & \multicolumn{2}{|l}{ Land size and products } \\
\cline { 2 - 3 } & Land size (ha) & Products (tons) \\
\hline $2015 / 16$ & 902,546 & $1,716,885$ \\
\hline $2016 / 17$ & 915,627 & $1,815,211$ \\
\hline $2017 / 18$ & 921,278 & $1,799,548$ \\
\hline $2018 / 19$ & 935,325 & $1,848,614$ \\
\hline $2019 / 20$ & 899,797 & $1,795,788$
\end{tabular}

Source Computed from Ministry of Agriculture Report (2020)

As Table 1 shows, 3,677,820 ha of land was transferred to the Federal Land Bank, of which 405,584 ha was leased to 137 investors for commercial agriculture. The three regions that contributed more than a million hectares of land to the bank were Gambella, Benishangul-Gumuz, and Oromia, because of the availability there of 'unused'11 land. The above source does not, however, explain why the three regions (Oromia, Amhara, and Somali) did not report the status of large-scale agriculture investment during the years indicated. Yet, although millions of hectares of land was accumulated in the Federal Land Bank, only $11.03 \%$ (405,584 ha) of it has been transferred to investors, and there is no data that compares the size of land transferred to investors to the country's total arable land. The Directorate for Agricultural Investment Support in the Ministry of Agriculture (2020) has provided complete data of the size of land transferred to large-scale agricultural investors in the 2019/20 fiscal year.

Accordingly, all regional states except Harari had land banks in 2020. The only reason why Harari region does not have land for agricultural investment is that it is a city-like region with a population of 183,344 , where $49.5 \%$ is engaged in agricultural activities and the remaining $50.5 \%$ is of a non-agricultural background (CSA 2007). Unlike the other eight regions, it does not have sufficient land for large-scale agricultural investment. Thus, land commercialisation through large-scale agriculture investment has continued to the present because the new reformist government, since April 2018, does not make any change to the state ownership of land.

Ethiopian government land commercialisation should also be assessed in terms of the types and purposes of crops produced by large-scale agricultural investment. Table 2 shows large-scale agricultural investment products during GTP II (20162020) mainly for export. The table illustrates the size of land used for producing the indicated tons of crops in each year from 2016 to 2020.

From the data, we can see that the highest yield from large-scale investment projects was in 2017, which accounted for 1,815,211 tons of crops from a total land of 915,627 ha. A single year (2019/2020) performance also indicates the achievements of large-scale agricultural investment for export as a source of currency earning. From

\footnotetext{
${ }^{11}$ Unused land is a misleading term to refer to land that is assumed to be uncultivated or unoccupied, and thus available to be developed for the benefit of economic growth, so that such 'idle' lands would become paragons of development.
} 
the five major crops (cereals, pulses, oilseeds, industrial crops such as cotton, and cash crops) listed in the report, cereals take the lead while industrial crops and oilseeds stand second and third, respectively, as a source of foreign earnings due to largescale agricultural investments. The Ministry of Agriculture (2020) has also narrated the thus far success stories of the large-scale agricultural investment programme in the country. First, it was reported that the country has fetched significant amount of foreign currency earnings. In addition to national image building, large-scale agricultural investment has created job opportunities ${ }^{12}$ for several citizens. It has also contributed inputs for the supply of raw materials for export and domestic industries. However, several challenges were observed in the implementation of investments. As opposed to the presence of large parcels of land in the land bank (see Table 1), it was reported that there is a shortage of sufficient land to be transferred for large-scale agriculture investment. Additionally, the investors' lack of commitment to start investment due to lack of infrastructure such as roads, imposition of high bank interest rate, and absence of the required support from host community at the investment destination are other serious challenges. Finally, the already commenced projects are reported to have low productivity due to the lack of appropriate incentive for importing farm machinery, and the lack of loan services.

Moreover, investors also complain that they face challenges from the government side. An investor whose land was taken away by the local administration in Gambella said the following:

I am one of the 100 investors who secured land in 2015. I leased 1000 ha of land from the region. But, I was evicted by the local administration because I was accused of taking land that was reserved by the federal government for special economic zone. Thus, it seems that they do not know what the federal government does in this regard. There is also inconsistency in the manual on how clients can acquire loan from the banks. There is also a delay in the process. For example, once you secure a land for investment, it will take one up to two years to get the loan. (Interview with My H S, 23 April 2020) (Addis Fortune, 16 April 2020)

In addition, the Development Bank of Ethiopia attributed the increase in nonperforming loans to prolonged unpaid loans and agricultural production failures mainly by large-scale commercial farms.

\subsection{Land Banks}

The development of land banks ${ }^{13}$ are closely connected with the lack of enough land supply for the fast-growing global urban population in both developed and

\footnotetext{
12 In its report (2020. 5), the Federal Ministry of Agriculture stated that large-scale agricultural investment has created an average of 15,125 full-time jobs and 276, 204 seasonal job opportunities during the second phase of the Growth and Transformation Plan (GTPII 2016-2020).

${ }^{13}$ Land banks in Ethiopia were often used to control landholdings in both rural and urban areas until 2019 when the new Federal Land Bank and Development Corporation was brought into being. However, this study could not trace any legal framework that bound the operation of land banks in the country.
} 
developing countries (Western Reserve Land Conservancy 2020, 1). In developed countries, land banks are involved in implementing urban renewal, preserving open spaces, and stabilising property and land values in a particular area (O'Brien et al. 2005,17 ) because the basic intent in the practice is to hold onto land until one proves that it is profitable to transfer it for various purposes. In the US, this strategy was developed as a mechanism to control urban development in the 1960s.

According to the United Nations Economic and Social Commission for Asia and the Pacific (UNESCAP 1993), land banking in developing countries.

implies that government acquires land in advance of needs. The main advantages are that it allows the purchase of land, relatively cheaply, for public purposes and provides a tool to influence the pattern of development in accordance to overall planning objectives.

In the Philippines, for example, a land bank was established in 1963 under the Agricultural Land Reform Code ${ }^{14}$ 'to finance the acquisition and distribution of agricultural estates for division and re-sale to small landholders and the purchase of landholdings by agricultural land tenants'. So, technically, 'a land bank is a land purchase/acquisition practice with the intention of being developed/matured to meet future development needs'. The land bank is a concept related to accessing land for the purposes of providing public services for housing, industry, agriculture, with land management, directing the land market and preventing land speculation (World Bank 2017, 723). With an attempt to clarify the purpose of land banks, Deutsche Gesellschaft für Technische Zusammenarbeit (GTZ 1998, 1), now Deutsche Gesellschaft für Internationale Zusammenarbeit (GIZ), ${ }^{15}$ provides some major guiding principles, which include improving access of the poor and other specific target groups to land, supporting the implementation of urban development projects, reducing inflation in land prices and land speculation, promoting public/private partnerships, and improving the land tenure structure in developing countries.

Some studies show that land banks are practised in African countries too. Areetey and Udry $(2010,1)$, for example, explored how they work in Ghana, a country where 'most land is held in customary tenure and its allocation is controlled by the leadership of stools, clans or families'. In their study, they described the institutionalisation of land banks as follows: the land would be deposited by acquiring it from land owners and, in turn, leased out to commercial farmers and developers who are individuals from the community (including chiefs) and the local government. In Nigeria, land banks are used in both urban and rural land management where land is acquired for future real estate development in urban areas and rural virgin lands are appropriated

\footnotetext{
${ }^{14}$ See Republic Act No. 3844. (1963). Agricultural Land Reform Code.

15 GIZ is a German organisation that supports Ethiopia's urban development activities through its 'Urban Governance and Decentralisation Programme (2005-2014)', which was commissioned by the German Federal Ministry for Economic Cooperation and Development (BMZ). The main objective of the support was to realise that urban centres and cities provide better services to their citizens and apply principles of urban good governance. The programme comprises the improvement of urban planning and public service provision, the improvement of urban financial management, the expansion of municipal knowledge management, and pro-poor urban development.
} 
for farming mainly with suitable topography, soil structure, and favourable climate. In the Republic of Rwanda, in 2016, the government started to use land banks to acquire land from individuals to provide low-cost houses by developers in the capital, Kigali (Republic of Rwanda 2017). So, the idea of the land bank is urban focused and a relatively new phenomenon to judge by its impacts in Rwanda.

Although we found limited literature on land banking practices in Ethiopia, a few documents (Ministry of Agriculture 2020; Proclamation No. 2001 EC) show that it has been prevalent in Ethiopia since 2009. The very nature and concept of land banks in the country entail the commodification of land that is not common in the traditional sense of land tenure. Today, several land-related actions, such as identifying and depositing land in the Federal Land Bank, have been exercised in different regional states, particularly those that have the potential to supply land for largescale agricultural commercialisation and urban areas such as Addis Ababa, where real estates and industries need large tracts of land. A business-oriented land bank, the Land Bank and Development Corporation, was established in 2019 as a 'profit government enterprise tasked with creating a methodological and inclusive national landholding development, management and administration system for maximization of socio-economic profit' (The Reporter 2019). Intro Africa (2019), based on an interview with Lensa Mekonnen, CEO of LBDC, stated that the bank has three strategic pillars ${ }^{16}$ : federal landholding management and administration, landholding business development, and federal landholding development.

Based on the 1995 Constitution and the 2005 Federal Land Administration and Land Use (Proclamation No. 456/2005), the federal government decided to actively encourage large-scale land investment and improve technical support for land investment. As per article 89(5) of the Constitution, which mandates the federal government to administer land on behalf of the people of Ethiopia, the Council of Ministers issued Proclamation 29/2001 EC, which provides that 'plots of over 5000 ha were to be administered by federal authorities and be included in land bank' (Keeley et al. 2014, 15-16). So, five land-abundant regions (Afar, Benishangul-Gumuz, Gambella, Oromia, and SPNNR) were instructed to prepare 'parcels of 5000 ha and above that would be suitable for large scale commercial agriculture'. Accordingly, by 2009, a

\footnotetext{
${ }^{16}$ Land Bank and Development Corporation of the Federal Democratic Republic of Ethiopia is a company established to identify all landholdings under FDRE federal institutions and public enterprises, tally all landholdings and secure title deeds; to properly develop and manage landholdings for maximum and all-inclusive economic benefit; to develop landholdings in a manner that facilitates service provision of federal government institutions and public enterprises; to methodically manage landholdings for maximised economic and social benefit; to ensure government's interest is protected when landholdings are transferred to private possession; to transfer previously issued title deed certificates to its name and serve as a data centre for decision making and develop the identified landholdings under its ownership through joint ventures (FDRE LBDC website, 15 April 2020). From this explanation, it is evident that, directly or indirectly, the purpose of the establishment of the new LBDC is to strengthen the ongoing land registration and certification programme in the country.
} 
total of 3.31 million ha was in the land bank in the five regions under the management of the Agricultural Investment Land Administration Agency (AILAA), which assumes an upward delegation by the regions. However, some regions accumulated more lands in their banks to lease to large-scale agricultural investors (Gebresenbet 2016, 15).

\subsection{Loan-Giving Financial Institutions}

The Ethiopian government has used all possible means to realise large agricultural commercialisation. In addition to controlling all the power of land allocation to investors at all levels, the federal government has been developing some mechanisms to offer financial support for investors in large agricultural investment. One such scheme was the facilitation of generous bank loans. Although the major governmentowned financing institutions are the Development Bank of Ethiopia, and the Commercial Bank of Ethiopia, there are also other private banks such as Awash and Abyssinia that provide loans for large-scale agricultural investment projects. According to the 2018 report from the Development Bank of Ethiopia, the loan portfolio concentration of the bank by economic sector shows that manufacturing accounted for Birr 26.9 billion (69.03\%) followed by agriculture, which accounted for Birr 6.95 billion $(17.84 \%)$ while financial service took Birr 3.4 billion $(8.72 \%)$ of the total loan.

Until 30 June 2019, the total loan portfolio of the Development Bank of Ethiopia consisted of 3779 loans, with a total loan balance of Birr 63.55 billion (Loan Portfolio Concentration Report, Development Bank of Ethiopia, July 2019). However, the bank gradually ceased to give loans to the agriculture sector due to the failure of the investors to pay back. According to this report, there were nine agriculture sub-sectors with a total of 889 loans; the borrowers in the three top most loan concentration sub-sectors are shown in Table 3.

Table 3 shows fibre crops (such as cotton) with a value of Birr 2.39 billion (5.06\%), oil crops with a value of Birr 2.05 billion (4.33\%), and horticulture (by flower industries) with a value of Birr 1.35 billion (2.86\%). Although the bank did not disclose

Table 3 Agricultural sub-sector loans whose concentration exposure ranked 1-3

\begin{tabular}{l|l|l|l|l}
\hline S.No. & Sub-sector & No. of loans & $\begin{array}{l}\text { Total portfolio excluding } \\
\text { Com. Balance (billion Birr) }\end{array}$ & $\begin{array}{l}\text { \% Share to total portfolio } \\
\text { excluding Com. Balance (\%) }\end{array}$ \\
\hline 1 & Fibre crops & 150 & 2,388 & 5.06 \\
\hline 2 & Oil crops & 283 & 2,047 & 4.33 \\
\hline 3 & Horticulture & 164 & 1,353 & 2.86 \\
\hline & Total & 597 & 5,788 & 12.25 \\
\hline
\end{tabular}

Source Loan Portfolio Concentration Report, DBE, July 2019 
the 2020 report, the following quote was taken from a newspaper, Addis Fortune (16 April 2020) to show the status of the current year:

Throughout the current half fiscal year, both public and private banks announced 18 auctions in just agriculture investments. Of total auctions, the share of private banks is Birr 7.3 million while the rest 72.1 million (91 pc) was issued by the two state-owned banks.

\subsection{Rural Land Registration and Certification}

Neo-liberal projects seems to dominate the EPRDF development ideology because the government tried to liberalise the economy in the name of the 'free market'. The economic policy put smallholder agriculture at the centre, with the justification that more than $80 \%$ of the total population depends on this main form of land use; 17.7 million ha of land was utilised by smallholder farmers for cultivation (CSA 2014). In addition, Beyene (2018) argues that it accounts for $90 \%$ of total agricultural production, which makes it an important area of policy, politics, poverty reduction, and land tenure at large. The government claimed that double-digit economic development was achieved because of the implementation of smallholder agriculture policy under the state monopolised land tenure system. Parallel to that was the plan for the commercialisation of smallholder agriculture, with the assumption that smallholder production will constitute sources of materials and inputs for the emerging manufacturing sector.

Yet, as smallholder agriculture is practised in areas where land is scarce and fragmented, this sector could not cope with the challenges of production relations and land tenure rights. Empirically, state land monopolisation inhibited investment in land and environment at individual farming households, since they consider the land belongs to the state with mere usufruct rights for them. Development partners who try to promote land privatisation have continued to warn that this, in turn, could result in reduced productivity and environmental degradation due to tenure insecurity. So, land registration and certification was introduced to fill these gaps.

As shown previously, the Ethiopian government has used every possible means to control land ownership. One is land registration, which has been implemented in two stages. First level land registration was initiated to secure the land titles of smallholder farmers and pastoralists under the Rural Land Administration and Land Use Proclamation No. 456/2005. This was a process of issuing simple temporary landholding certificates, which did not have information, such as geo-referencing and maps of land parcels (Ministry of Agriculture 2013). The certificate cites land size, uses, borders, and names of proprietors. If a plot is a common holding of spouses, the certificate bears the names of both. However, the second stage ${ }^{17}$ registration was implemented to rectify the weaknesses observed in the first stage by using georeferences and maps of parcels to minimise disputes over land. Table 4 shows the

\footnotetext{
${ }^{17}$ As the second stage of the land registration and certification process is at its pilot level, there is no accurate data to tell the success stories currently.
} 
Table 4 Land registration in four regions

\begin{tabular}{l|l|l|l|l|l}
\hline Regions & Amhara & Oromia & SNNPR & Tigray & Total \\
\hline Area $\left(\mathrm{km}^{2}\right)$ & 170,752 & 350,000 & 113,323 & 80,000 & 714,075 \\
\hline Population (mil) & 17.2 & 28.0 & 16.0 & 4.4 & 65.6 \\
\hline Rural woredas & 128 & 264 & 134 & 34 & 560 \\
\hline Kebeles & 3,146 & 6,419 & 3,586 & 695 & 13,846 \\
\hline Kebeles per woreda & 25 & 24 & 27 & 20 & 25 \\
\hline Rural households (mil) & 3.696 & 5.314 & 2.848 & 0.924 & 12.782 \\
\hline Estimated total parcels (mil) & 19.634 & 20.335 & 6.277 & 3.431 & 49.676 \\
\hline First-level certificates issued (mil) & 2.749 & 1.800 & 1.900 & 0.906 & 7.355 \\
\hline Completion calculated (\%) & 74 & 34 & 67 & 98 & 58 \\
\hline Second-level certificates issued & 1,612 & 3,000 & 0 & 0 & 4,612 \\
\hline
\end{tabular}

Source World Bank $(2012,51)$

coverage of Ethiopian rural land registration and certification up to 2012 (World Bank 2012). As the second level registration was at its pilot stage, the percentage of completion in the table refers to the performance of the first level.

Despite all the achievements that the government actors claim, there are some concerns with respect to the legal issues and scope of land registration, and the certification programme itself. Apart from what is mentioned in the Rural Land Administration and Land Use Proclamation (Proclamation No. 456/2005, and MoFED 2002), which does not provide any detail, there is no legal document that governs implementation. In addition, Davies $(2008,243)$ argues that as Ethiopia's land registration and certification project encompasses several agendas, such as tenure security, conservation, authority enhancement, and gender, which are haphazardly placed together, this puts the programme's success and continuity under question. Yet, it is at its second stage of implementation with the support of foreign donor agencies.

\section{Role of Transnational Development Agencies}

Do transnational institutions/external forces influence Ethiopian land policy and land administration? Evidence shows that several institutions, including the World Bank and other bilateral organisations, are working towards land policy reforms in sub-Saharan African ${ }^{18}$ countries (Abdo 2014). One may argue that Western powers

\footnotetext{
18 The LEGEND Report (2016, 13), for example, shows that DFID supports many African countries through its various land programmes. For instance, it helps Ethiopia through the Land Investment for Transformation (LIFT)-Wealth Creation, while Mozambique has received support from DFID for its Community Land Use Fund, Mozambique Land Action (MOLA), and Global Legal Empowerment Initiative. Rwanda also receives support from the 'Rwanda Land Tenure Regularisation Programme. Tanzania has run the 'Tanzania Land programme' while South Africa has received support for the 'Urban Land Reform-Urban Land Market' programme. Ghana forest governance, markets and
} 
dictated land reforms in colonial African countries during the colonial era, and we can still see the influence of their interests and ideologies in the land reforms of Africa even after the end of the Cold War. These ideologies include pro-private land ownership and market liberalisation, and they have been pushing the Ethiopian government towards them. Donors believed that tenure insecurity, particularly in the agriculture sector, was the major inhibiting factor in the economic growth of the country because all development endeavours revolve around land tenure rights (Steven 2018). However, as the government is unwilling to change the state-public ownership of land, they could not go farther. Thus, their partnership on the land tenure issue has been through the implementation of rural land registration and certification. Therefore, Ethiopia has received much support from countries such as the US and the UK through their overseas development agencies. It is often pronounced that these agencies are very important to give political and technical expertise in land management. In the following sections, we examine the role of two organisations, namely USAID and the UK Department for International Development (DFID), in intervening in Ethiopian land policy formulation and implementation strategies after the Cold War.

\subsection{USAID}

USAID $^{19}$ has been operating in Ethiopia since 1961. It appears with different development intervention strategies in alignment with the country's development policies. In its Ethiopia Land Policy and Administration Assessment report (2004, 25-27), USAID identified five areas of intervention in Ethiopian land policy, land administration and other related support programmes. Of these, I will highlight two, which are closely related to land administration. The first was the 2013-2018 project, the Ethiopia Land Administration to Nurture Development (LAND), which worked at the national and regional levels to improve the legal and regulatory framework of land tenure and property rights in Ethiopia. The LAND project builds on two previous projects. The first is the Ethiopia Strengthening Land Tenure and Administration Program (ELTAP) (2005-2008) and the Ethiopia Land Administration Program (ELAP) (2008-2012) to improve land governance and land administration and strengthen land tenure rights in Ethiopia and, thereby, promote economic growth, increase agricultural productivity, reduce conflict and resource degradation, and improve women's rights to control and manage assets. It has three objectives.

climate initiatives were also undertaken with financial aid from DFID. Of course, the 'Investment Climate Facility' programme was designed for various African countries.

${ }^{19}$ USAID has been supporting Ethiopia since the beginning of the 1960s. In 1962, for example, it set priorities that include education, agriculture, fisheries, health and sanitation, community development, social welfare and housing, industry and mining, and transportation. (See 'Evolution of USAID Development Priorities in Ethiopia: Details of USAID programs and funding from 1961-2013'.). 
First, it aimed to support national and regional governments to improve land administration and land use laws. Second, it worked to improve the efficiency of Ethiopia's land administration institutions in the areas of land use rights certification and transactions. And third, to encourage pastoral regions to introduce certification of communal land use rights and management of natural resources. From these objectives, USAID's interference in Ethiopian land policy implementation programmes becomes evident.

In November 2019, USAID declared the development of a new project with the theme 'Invest to Improve Land Governance in Ethiopia'. This US\$11 million-worth project was assumed to support the government of Ethiopia towards increasing land tenure security, improve land use rights for pastoralists and farmers-especially, those of women to increase farm productivity and incomes among families in rural areas. 'Improving planning, policy, and land management is critical to helping Ethiopian farmers and families reap the fruits of their labour more fully, and have better opportunities for themselves and their children to fulfil the bright future they deserve' (USAID Mission Director).

This new project has five intervention areas. The first one is land policy itself. It is clearly stated in the plan document that 'there is a great need to help the Ethiopian leadership think about how it can modify land policy and administration in ways that will encourage efficient farmers to produce more and improve their land management without reducing their livelihood security' (USAID 2019). The second area of intervention is capacity building to administer land. This supports the country in the process of recording and disseminating information about the ownership, value, and use of land and associated resources.

Thirdly, USAID has planned to intervene with the assessment and determination of land use rights in Ethiopia with the belief that, although the Ethiopian Constitution guarantees the rights of peasants and pastoralists to free land and protection against eviction or displacement subject to certain condition, there is no sufficient evidence as to the 'systematic procedures for determining and securing these use rights' (USAID 2019, 26). So, the plan is to intervene in the land certification programmes to identify and record land users and their landholdings. Fourthly, USAID intends to create public awareness by enabling people to become aware of their rights and obligations and install the mechanisms to enforce those rights, and by educating them about the objectives and structures of a decentralised land management system. This would be followed by a plan to undertake an assessment of the perception of land holders regarding the land certification programme, assessing the long-term sustainability of the programme itself and, finally, to develop mechanisms to monitor changes in land use, investment, and land tenure security.

From the above-mentioned points, it is evident that the US is investing in Ethiopian land administration through its international agency USAID by penetrating all forms of Ethiopia's land policy implementation activities, thereby becoming another tool for the Ethiopian government to build its land-controlling power.

Next, we will examine how a UK-based international agency, DFID, plays a similar role in the Ethiopian land policy and land administration activities. 


\subsection{DFID}

Similar to the US government intervention through USAID support strategies, the UK government also offers land policy and land management support to Ethiopia through its international organisation, DFID. ${ }^{20}$ In its portfolio review (2016) report 'Land: Enhancing Governance for Economic Development' (LEGEND), DFID indicated that it funds around 25 programmes that work on land globally. The report focused on exploring how investment facilities that receive substantial support from DFID deal with land issues in their investment in commercial agriculture and how infrastructure was handled. In this report, it was indicated that DFID support has produced impressive results in delivering large land registration programmes for strengthening land tenure rights for women. DFID's main rationale for promoting better land governance in Ethiopia is that stronger land tenure improves economic growth and reduces income poverty (Henley and Hoffler 2016, 7), but the government also uses this external support for controlling land and the land-connected daily activities of citizens.

According to its portfolio report (2016),DFID is supporting land-related activities in several African countries including Ethiopia. The support programmes include components such as strengthening land titling and land administration, forest management and land tenure, land reform as part of the broader reforms to improve the business climate, and urban development programmes that work with local government to improve services and lives of citizens in slums, and the poorest and vulnerable groups (LEGEND Report 2016, 15-17). Henley and Hoffler (2016, 12) identified two categories of DFID support for different African countries including Ethiopia. These are labelled as 'core' and 'substantial' land components. ${ }^{21}$

DFID supports Ethiopia through its Land Investment for Transformation (LIFT) project, which has six themes: Land tenure and certification, protecting land rights, land administration, access to finance, land rental, agricultural inputs for sustainability (DFID Annual Review, January 2020). For the above list of core and substantial land components, Ethiopia shares nearly $£ 67$ million (LEGEND report 2016, 13) for the LIFT as a DFID core land programme. LIFT was implemented during 20132020 based on the experience from the Rwanda Land Tenure Reform Programme

\footnotetext{
${ }^{20}$ As part of DFID's prioritisation, a specific advisory group on Land Tenure and Policy was established by the UK government. This group convened a series of workshops and conferences on land, providing advisory support. It also worked to influence policy and programming on land by the World Bank and EU, as the major multilateral donors taking forward work on land. After 2003, DFID scaled back its work on land. This was because it was thought the department did not have the internal capacity to engage beyond a coordinating role and because its experience at the time suggested that to pursue property rights programmes, there needed to be political consensus for reform from governments in its partner countries, who often had 'strong views on land tenure'. It published a policy paper in 2007 that highlighted how improving poor people's access to land was one of DFID's priorities and set out its support to country-led approaches. (See LEGEND: DFID Land Portfolio and Programmes: an Overview $(2016,10)$.).

${ }^{21}$ Henley and Hoffler $(2016,12)$ identified 'core' programmes as those that have land governance as the main focus while 'substantial' programmes are those that have a different or broader land component, either strengthening land tenure or improving land governance.
} 
(LTRP) and Land Tenure Regularisation (LTR), which lasted from 2003 to 2018 with a success story that tells that 11.4 million parcels of land were demarcated, 8 million titles were issued, and 7.4 million titles were collected (DFID LIFT Technical Report 2019). DFID planned to scale this up in Ethiopia (LIFT support) to implement rural land certification aiming at driving investment and increasing productive land use particularly in four regions (Amhara, Oromia, SNNPRS, and Tigray). The DFID review report (2020) shows that there were several achievements reached by the LIFT intervention strategies in Ethiopian land administration. For example, the support enabled the demarcation of 15,186,635 parcels of land, the approval of $13,260,949$ certificates, the preparation of $12,918,846$ certificates, and the distribution of 10,907,158 certificates to landholders (DFID LIFT Annual Review 2020).

In general, Western agencies' development supports go to Ethiopia with a significant ambitious plan to influence the country's land policy and citizens' tenure security. Their main ambition was to influence the government to privatise land. However, they seemed to lose their power eventually, for the Ethiopian government took the position that land would in no circumstances be privatised. So, they were trapped by the government and ended up contributing for the state monopolisation of land in the country. From the above two cases, USAID and DFID, we can understand that their areas of intervention are overlapping and reinforcing each other with some minor differences in their activities, with some sense of competition. From the support components of the agencies, one can understand that they greatly influence Ethiopian land administration practices while they themselves are also influenced by the government in trimming down their support to the level of the satisfaction of the government, not fully addressing the demands of millions of citizens whose livelihoods are directly connected to land tenure questions.

\section{Corruption and Large-Scale Agricultural Investment}

The post-Cold War Ethiopian land governance policy creates a loophole for corruption as a result of the state's intention to tighten its power over land ownership. The present land holding system of the country reflects the changes and continuities in the political economy of the country because land remained in the hands of a few feudal land lords during the imperial period and full ownership of the state during the military command economy, 1974-1991 (Misganaw 2019, 1). Today, despite the claim that the government works towards realising a free-market economy, land is still owned by the state with a high risk of corruption in its administration (Rahman 2018, 7).

Lindner (2014) has listed several factors that expose the Cold-War Ethiopian land administration system to corruption. These factors are interrelated: ranging from policy formulation to investment implementation stages. In support of this, Lindner $(2014,5)$ argues that 'land administration system in Ethiopia has a potential for 
corruption because of lack of clear policies, weak institutions, lack of transparency, and lack of public participation in the land related decision-makings'.

In addition, Plummer (2012, 303) has conceptualised the country's land-related corruption to appear at 'upstream and downstream' levels. According to Plummer, corruption occurs at the upstream level during policy formulation or in the institutions that allocate budgets for land administration tasks; the elites capture public assets through a range of mechanisms, such as influencing policy and legislation at the expense of society's benefit. Similarly, corruption occurs in the institutions that formulate and allocate budgets during procurement, as staff often conspire with suppliers, or due to nepotism, fraud, or bribery. Land sector corruption has also been a point of discussion after the April 2018 new government reform in Ethiopia. Several mainstream media, such as TV and radio, have discussed this issue. They have presented interviews and documentaries from both rural and urban areas. The discussions include success stories in the land transfer processes to investors, sources of finance for large-scale agricultural investments, and the magnitude of corruption in accessing both land and financial loans for agricultural investments. Here, we take the case of land-related corruption in Benishangul-Gumuz Regional State which is a region where large-scale agricultural investment is implemented. On 5 July 2020, FANA TV presented a documentary film supported by individual interviews with the regional governor (Ashadle Hasen), the former regional head of land administration (Mr. Musa), Mr. Geleta Hailu, who is the current head of the regional land administration, and two investors from the agriculture and hotel investment sectors.

The interview results, though they may not be representative of other regions, are briefly presented below to shed light upon the scale of corruption in land acquisition and access to financial loans for investment in the region. We start with the interview with the regional governor.

Journalist: How could investors access land in your region before the reform and after?

Regional governor: To tell the truth, about 600 investment licences were given in the last few years. But the result was not as expected for different reasons. The so-called investors come here in different ways. Some of them were assigned from the central government to our region in the name of technical advisors for development activities. Others come through a network of federal level political officials just to secure land.

Then the journalist interviewed the former head of the regional land administration (Mr. Musa).

Journalist: How could investors access land for investment in your region?

Mr Musa: The land transfer process was not transparent in the past (before the new reform). Simply we were given orders/instructions from above, from the people in the ruling party [EPRDF] to allocate land to people whom they want.

In the meantime, a video of damaged agricultural machinery was shown as a background to the interviews. These included damaged bulldozers, tractors, and harvesters, lying ruined in the grass. Later two other investors, Mr. Kefyalew and Mr. Assefa, were interviewed one after the other on the same topic, to understand how they were able to get loans for their investment activities before and after the 2018 reform. Both of them were running agricultural investment and hotel businesses. 
Journalist: Can you tell me how you got the land and bank loan for your investment?

Mr Kefyalew: Before the reform, I approached the Commercial Bank of Ethiopia several times to get loan but could not get any. But at the same time some other people were able to get it without any difficulty. They have the network. So, I returned the investment licence and stopped talking about bank loan further. The bank loan system was biased for it was networked by individuals and politicians.

Then the journalist continued his interview with the other investor, Mr. Assefa.

Journalist: How did you get land and loan for your investment activities here?

Mr. Aseffa: Whenever I tried to get a bank loan, a certain organised group harassed me to prevent me from investing. But for themselves, they used the existing political security system as an instrument to get land easily. Such people can get land within a few days. Things were networked at the top. But now I see the situation is changing after the new reform.

Mr. Geleta Hailu, the current head of the regional land administration office, was also included in the interview.

Journalist: How do you see the success of investment projects in your region?

Mr. Geleta: Many people used to come to this region for agricultural investment. They took loan from banks, and went back to Addis Ababa to construct complex buildings with the money. They did not invest here at all. So, now their license has been cancelled and the land allocated for them has been transferred to the land bank.

Towards the end of the interviews and documentary film, the regional governor appeared and said: 'The regional state did not have any decision-making power over land in the past. Information and data were hidden there at the federal level. We have no data now to talk about.' But one should not forget that what Plummer (2012) calls downstream corruption appears all the way during land transfer or land certification processes because local authorities or politicians abuse their power in the land allocation for investment.

In addition, Addis Fortune, in its 16 April 2020 edition, exposed that the failure of the large commercial farms in Gambella regional state has a domino effect on loan-giving banks. The case in point was the Development Bank of Ethiopia, which was the major financier of large-scale agricultural farms in the country. However, due to the poor performance of the farms, the bank ceased to extend loans for commercial farms as of March 2020 to restructure its performance in loans and loan disbursement. The main reason behind this decision was the extent of corruption in commercial farms in the region where the bank was even deceived into 'giving two loans for a single agriculture project'.

According to the above source, the bank incurred a $100 \%$ increase in its nonperforming loans portfolio to Birr 3.4 billion in 2014-2015. The bank's official report attributed this increase to prolonged unpaid loans and agricultural production failures mainly by large-scale commercial farms. For example, BHO, an Indian company, which was offered Birr 89 million loan, disappeared after developing less than 3000 of the total 27,000 ha of land it was granted in Gambella regional state. At the same time, 98,800 ha of land was retaken from the Indian Karuturi company, because 
it developed only 1200 ha though it had received 100 ha of land. Being the major areas for large-scale agricultural investment in Ethiopia, the above two regional states (Benishangul-Gumuz and Gambella) might have many more cases to illustrate the magnitude of land sector corruption. This calls for further full-fledged research.

\section{Conclusion}

This chapter explored state-sponsored land commercialisation in Ethiopia after the Cold War. This was realised by examining the institutions that were designated for controlling land resources, thereby limiting the freedom of citizens over land tenure rights, which are mainly connected to ownership security issues. It is related to the often overstated land use rights - the right that any rural family should exercise to use land for grazing, growing crops, or collecting minor forestry products for household consumption, or sometimes for market purposes to augment income, though it is highly regulated in its practical sense (1995 Constitution). As land is solely owned by the state, citizens do not actually exercise their rights; this reflects the land holder's level of freedom to make decisions on how they should use the land and their agency of land utilisation; it is the government that determines what kind of crops a family, a farmers' association, or a farmers' union should cultivate on clusters of lands. In addition, under the Constitution citizens' land transfer rights are restricted by the land laws.

Land banks, as a state institution, are a major means of consolidating state power over land administration by creating and recreating high-value land zones for undertaking large-scale agricultural investment. Evidence shows that there are success stories among these investment projects, although their productivity remains under question. However, the picture of a success story is more complex, as seen in the case of agricultural investment projects in some areas such as Gambella and Benishangul-Gumuz regional states.

Finally, when we consider the overall challenges of Ethiopian land policy after the Cold War, there is a contradiction between the assumptions of the Constitution and specific land laws. The state exercises power over land and is often facilitated by government agents, such as the financial institutions and foreign aid organisations, which often include land components in their support.

Conceptually, transnational institutions are working towards influencing the Ethiopian government to guarantee land security for citizens but, practically, they are also co-opted to be the third hand to support state-sponsored land commodification. Specific land-related intervention strategies are carefully chosen and implemented by the donor agencies and the federal government of Ethiopia so that regional states and citizens cannot voice their alternatives or choices, leading to dissatisfaction and conflict among different stakeholders. This, in turn, has resulted in the failure of many large-scale agricultural projects, which have led to the cancellation of investment 
licences. The country now needs to examine its land laws so that a robust alternative land holding system will be available to facilitate investment and to ensure more sustainable use of land, which is the most important resource for an agrarian country like Ethiopia.

Acknowledgements This paper was produced with the support of African Studies Centre at Tokyo University of Foreign Studies (TUFS), Japan.

\section{References}

Abdo, M. 2014. State policy and law in relation to land alienation in Ethiopia. Ph.D. thesis, University of Warwick.

Adal, Y. 2002. Review of landholding systems and policies in Ethiopia under the different regimes. Ethiopian Economic Policy Research Institute Working Paper No. 5.

Aryeetey, E., and C. Udry. 2010. Creating property rights: land banks in Ghana. American Economic Review 100 (2): 130-134. https://doi.org/10.1257/aer.100.2.130.

Bertazzini, M. C. 2018. The long-term impact of Italian colonial roads in the horn of Africa, 1935-2000 (Working Papers No. 272-January 2018).http://eprints.lse.ac.uk.

Beyene, A., ed. 2018. Agricultural transformation in Ethiopia: State policy and smallholder farming. London: Zed Books.

Binayew, G. 2015. Historiographical review of the current debate on Ethiopian land tenure system. African Journal of History and Culture 7 (2): 44-51. https://doi.org/10.5897/AJHC2014.0230.

Central Statistics Agency (CSA). 2007. Housing and census of Ethiopia, administrative report. Addis Ababa.

Cohen, J.M. 1973. Ethiopia after Haile Selassie: The government land factor. African Affairs 72 (289): 365-382.

Cohen, J.M. and D. Weintraub. 1975. Land and peasants in imperial Ethiopia: The social background to a revolution. Assen: van Gorcum.

Cotula, L., ed. 2007. Changes in 'Customary' land tenure systems in Africa. London: IIED.

Crewett, W., and B. Korf. 2008. Ethiopia: Reforming land tenure. Review of African Political Economy 35 (116): 203-220.

Crewett, W., A. Bogale, and B. Korf. 2008. Land tenure in Ethiopia: Continuity and change, shifting rulers, and the quest for state control. CAPRi Working Paper 91. International Food Policy Research Institute. http://dx.doi.org/https://doi.org/10.2499/CAPRiWP91.

Crummey, D. 2000. Land and societies in the Christian kingdom: From the thirteenth to the twentieth century. Addis Ababa: Addis Ababa University Press/University of Illinois Press.

Davies, S. 2008. The Political Economy of Land Tenure in Ethiopia. A Thesis Submitted for the Degree of PhD at the University of St. Andrews. http://hdl.handle.net/10023/580.

Department for International Development (DFID). 2016. Land: Enhancing governance for economic development (Legend) annual report. London.

Department for International Development (DFID). 2020. Evaluation annual report. London.

Development Bank of Ethiopia. 2018. Fourth quarter loan portfolio concentration report. Addis Ababa: Ethiopia.

Development Bank of Ethiopia. 2019. Fourth quarter loan portfolio concentration report. Addis Ababa: Ethiopia.

Federal Democratic Republic of Ethiopia (FDRE). 1995. Constitution of the federal democratic Republic of Ethiopia. 
Gebresenbet, F. 2016. Land acquisitions, the politics of dispossession, and state-remaking in Gambella Western Ethiopia. Africa Spectrum 51 (1): 5-28. https://doi.org/10.1177/000203971 605100102.

González-Ruibal, A. 2010. Fascist colonialism: The archaeology of Italian outposts in Western Ethiopia (1936-1941). International Journal of Historical Archaeology 14(4): 547-574.

GTZ (Deutsche Gesellschaft für Technische Zusammenarbeit). 1998. Guiding principles: Land tenure in development cooperation. www.mekonginfo.org/mrc.html/tenure/.

Hebo, M. 2006. Land, local customs and state policies: Land tenure, land disputes and disputes settlement among the Arsi Oromo of Southern Ethiopia. Kyoto: Nakanishi Printing Co Ltd.

Henley, G. and H. Hoffler. 2016. Legend report, DFID's land portfolio and programmes: An overview. UK Department for International Development.

Hoben, A. 1973. Land tenure among the Amhara of Ethiopia: The dynamics of cognates' descent. Chicago: Chicago University Press.

Keeley, J., M.S. Wondwosen, E. Abdurehman, and L.K. Admasu. 2014. Large-scale land deals in Ethiopia: Scale, trends, features and outcomes to date. London: IIED.

Larebo, H. 1994. The building of an empower: Italian land policy and practices in Ethiopia, 19351941. Oxford: Clarenton Press.

Lavers, T. 2018. Responding to land-based conflict in Ethiopia: The land rights of ethnic minorities under federalism. African Affairs 117 (468): 462-484. https://doi.org/10.1093/afraf/ady010.

LIFT and Co Corp. 2020. Annual review highlights.

Mengisteab, K. 1990. Ethiopia: Failure of land reform and agricultural crisis. New York: Greenwood Press.

Ministry of Agriculture (MOA). 2013. Rural land registration and administration. SLM Knowledge Base. Ethiopia.

Ministry of Agriculture (MOA). 2020. Agricultural Investment Support Directorate. Large scale agricultural investment land data. Addis Ababa: Ethiopia.

Ministry of Finance and Economic Development. 2006. Ethiopia: Building on progress a plan for accelerated and sustained development to end poverty (PASDEP) (2005/6-2009/10). Volume I. Addis Ababa: Ethiopia.

Misganaw, G. 2019. Corruption in the post 1991 urban land governance of Ethiopia. In A Paper presented at the conference on land policy in Africa. Abidjan, Côte d'Ivoire, 4-8 November.

Nega, B., B. Adnew, and S.G. Sellasie. 2003. Current Land Policy Issues in Ethiopia. Land Reform (Ethiopian Economic Policy Research Institute, 2003/9 special edition).

O’Brien, K., K. Toth, C. Robey, C. Gollan, M. Sattler, J. Duritsky, and S. Hudecek. 2005. Best practices in land bank operation. Urban Publications 0123 165. https://engagedscholarship.csu ohio.edu/urban_facpub/165.

Ofcansky, T. and L. Berry (eds.). 1991. Ethiopia: A country study. Washington, DC: GPO for the Library of Congress. Federal Research Division.

Pankhurst, R. 1966. State and land in Ethiopian history. Addis Ababa: Institute of Ethiopian Studies and Faculty of Law, Haile Selassie I University in association with Oxford University Press.

Plummer, J., ed. 2012. Diagnosing corruption in Ethiopia: Perceptions, realities, and the way forward for key sectors. Washington, DC: World Bank.

Rahman, K. 2018. Overview of corruption and anti-corruption in Ethiopia. Transparency International.

Rahmeto, D. 1984. Agrarian reform in Ethiopia. Uppsala: SIAS.

Rahmeto, D. 1992. The land question and reform policy: Issues for debate. Dialogue 1 (1): $43-57$.

Rahmeto, D. 1994. Land policy in Ethiopia at cross-roads. In Land tenure and land policy in Ethiopia after the Derg, ed. R. Desalegn. Norway: Reprocentralen AVH.

Rahmeto, D. 2011. Land to investors: Large-scale land transfers in Ethiopia. Forum for Social Studies, Addis Ababa, Ethiopia.

Republic of Rwanda, Ministry of Infrastructure. 2017. Rwanda acquires land bank to ease housing. Republic of Rwanda.

Schwab, P. 1978. Cold war on the Horn of Africa. African Affairs 77 (306): 6-20. 
Solomon, D.D. 2020. Ethiopia history of land tenure and the present land governance: The case of Oromia Region. International Journal of Academic Research and Development 5 (1): 33-49.

Teklu, T., and L. Adugna. 2004. Factors affecting entry and intensity in informal rental land markets in Southern Ethiopian highlands. Agricultural Economics 30 (2): 117-128. https://doi.org/10. 1016/j.agecon.2003.11.016.

Temesgen, S. 2020. Legal and institutional frameworks regulating rural land governance in Ethiopia: Towards a comparative analysis on the best practices of other African countries. Beijing Law Review 11: 64-98. www.scirp.org/journal/blrISSN.

The Reporter. 2019. Audit contributes to the arrest of officials, business people. The Reporter 30 (2): 117-128.

United Nations Economic and Social Commission for Asia and the Pacific (UNESCAP). 1993. Municipal land management in Asia: A comparative study. www.unescap.org/huset $/ \mathrm{m} \_l$ land/toc. United Nations International Children's Emergency Fund (UNICEF) Ethiopia. 2019. Education for pastoralist children (A Bulletin, March 2019).

United States Agency for International Development (USAID). 2004. Ethiopia land policy and administration assessment. USAID: ARD Inc.

USAID. 2019. Invest 2019 Annual report.

Western Reserve Land Conservatory. 2020. Report. (Info@wrlandconservancy.org).

World Bank. 2017. Sustainable land management project report. Washington, DC.

Zewde, B. 2001. A history of modern Ethiopia 1855-1991, 2nd ed. Addis Ababa: Addis Ababa University Press.

\section{Proclamation}

31/1975. Proclamation for Public Ownership of Rural Lands.

47/1975. Proclamation for Government ownership of urban lands and extra urban houses.

89/1997. Proclamation for Federal Rural Land Administration.

455/2005. Proclamation for Expropriation of Landholdings for Public Purposes and Payment of

Compensation.

456/2005. Proclamation for Federal Land Administration and Land Use.

Open Access This chapter is licensed under the terms of the Creative Commons Attribution 4.0 International License (http://creativecommons.org/licenses/by/4.0/), which permits use, sharing, adaptation, distribution and reproduction in any medium or format, as long as you give appropriate credit to the original author(s) and the source, provide a link to the Creative Commons license and indicate if changes were made.

The images or other third party material in this chapter are included in the chapter's Creative Commons license, unless indicated otherwise in a credit line to the material. If material is not included in the chapter's Creative Commons license and your intended use is not permitted by statutory regulation or exceeds the permitted use, you will need to obtain permission directly from the copyright holder.

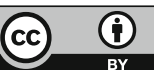

